\title{
UJI AKTIVITAS ANTIINFLAMASI GEL EKSTRAK KULIT MANGGIS DENGAN VARIASI KONSENTRASI
}

\section{ANTIINFLAMATION ACTIVITY TEST OF MANGOSTEEN EXTRACT GEL WITH VARIATION CONCENTRATION}

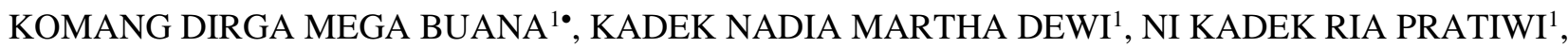 \\ DWI MEGA PERMATAHATI ${ }^{1}$, PUTU RIKA JESIKA PUTRI ${ }^{1}$, LUH PRATIWI DIVA YANTI ${ }^{1}$, \\ DEWA AYU SWASTINI ${ }^{1}$ \\ ${ }^{1}$ Program Studi Farmasi, Fakultas MIPA, Universitas Udayana
}

\begin{abstract}
Abstrak: Inflamasi merupakan respon pertahanan tubuh terhadap invasi benda asing, kerusakan jaringan atau keduanya. Inflamasi ditandai dengan adanya rubor (kemerahan), kalor (panas), dolor (nyeri) dan tumor (pembengkakan). Di alam terdapat berbagai senyawa yang dapat memberikan aktivitas sebagai antiinflamasi, salah satunya adanya senyawa yang terkandung dalam kulit buah manggis. Ekstrak kulit buah manggis yang memiliki aktivitas sebagai antiinflamasi, yakni $\gamma$-mangostin. Kandungan $\gamma$-mangostin pada kulit buah manggis diketahui dapat menghambat jalur aktivitas siklooksigenase (COX-2) dan dapat menurunkan level dari $\mathrm{PGE}_{2}$.Penelitian dilakukan dengan 6 ekor mencit yang menjadi 2 kelompok uji. Kelompok I sebagai kelompok kontrol (1 ekor mencit untuk Kontrol Positif, 1 ekor mencit untuk Kontrol Negatif dan 1 ekor mencit untuk Kontrol Normal) dan kelompok II sebagai kelompok uji sebanyak 3 ekor mencit. Pada tiap kaki kanan belakang mencit pada kontrol negatif dioleskan 100mg basis sediaan uji, pada mencit kontrol positif dioleskan 100mg voltaren emulgel dan pada kontrol normal tidak diberikan apapun. Sedangkan pada kelompok II dioleskan 100mg sediaan uji. Setelah diberi perlakuan, terhadap kaki kanan belakang mencit seluruh kelompok kecuali kelompok kontrtol normal diinjeksikan larutan karagenan sebanyak $0,1 \mathrm{~mL}$. Diukur volume kaki kanan belakang mencit hingga tanda batas yang telah diberikan pada menit ke-30, 60, dan 90 terhitung setelah pemberian injeksi karagenan (Vt). Nilai persen aktivitas antiinflamasi sediaan uji yang paling mendekati kontrol positif (voltaren emulgel) adalah sediaan uji dengan konsentrasi 0,1\% yaitu 25,07\%; 55,28\%, dan $82,33 \%$ pada menit ke-30, 60 dan 90 secara berturut turut.
\end{abstract}

Kata kunci: ekstrak kulit manggis, uji aktivitas antiinflamasi, variasi konsentrasi

Abstract: Inflammation is the body's defense response to the invasion of foreign objects, tissue damage or both. Inflammation is characterized by the presence of Rubor (redness), heat, and dolor (pain) and tumors (swelling). In nature there are various compounds that can provide activity as an anti-inflammatory, one of which is a compound contained in the skin of mangosteen. Mangosteen rind extract which has antiinflammatory activity, namely $\gamma$-mangostin. The $\gamma$-mangostin is known to inhibit the cyclooxygenase (COX2) activity pathway and can reduce the level of PGE2. This research was carried out using 6 mice which that was divided into 2 treatment groups. Group I as a control group (1 mouse for Positive Control, 1 mouse for Negative Control and 1 mouse for Normal Control) and group II as a test group with different concentration of gel mangosteen rind extract on 3 mice. On each right leg the mice on the negative control were applied $100 \mathrm{mg}$ of the basis of the gel mangosteen rind extract, on the positive control mice 100mg of the emulgel was applied and on normal controls nothing was given. Whereas in group II $100 \mathrm{mg}$ of the gel mangosteen rind extract was applied. After being treated, the entire right group of mice's right leg except the normal control group were injected with $0,1 \mathrm{~mL}$ of carrageenan solution. The volume of the mice's right leg is measured up to the mark limit that has been given in the 30,60 , and 90 minutes from the injection of carrageenan $(\mathrm{Vt})$. The percent value of anti-inflammatory activity of the test preparation which is the closest to positive control (voltaren emulgel) is the gel mangosteen rind extract with a concentration of $0.1 \%$, that are $25.07 \% ; 55.28 \%$ and $82.33 \%$ in the 30, 60 and 90 minutes respectively.

Keywords: anti-inflammatory activity test, concentration variation, mangosteen rind extract.

\footnotetext{
• email korespondensi: dirgamegabuana01@gmail.com
} 


\section{PENDAHULUAN}

Suatu produk kesehatan berupa obat dapat diaplikasikan dan dipasarkan di masyarakat harus melalui beberapa tahap pengujian. Pengujian suatu obat dapat dilakukan melalui uji praklinik dan uji klinik. Uji praklinik dalam farmakologi merupakan suatu proses uji yang dilaksanakan pada hewan coba dan atau pada bahan biologi lainnya untuk membuktikan kebenaran khasiat dan keamanan secara ilmiah suatu bahan yang sebelumnya diduga memiliki khasiat obat atau terhadap bahan obat yang telah beredar di masyarakat (Meles, 2010).

Hewan percobaan banyak digunakan dalam studi eksperimental dari cabang medis dan ilmu pengetahuan. Pemakaian hewan coba untuk penelitian klinis pada manusia telah memberikan kontribusi besar terhadap pemahaman tentang berbagai proses fisiologis dan patologis yang mempengaruhi manusia (Meles, 2010). Salah satu hewan coba yang sering digunakan dalam penelitian adalah hewan pengerat atau rodensia yang penggunaannya sekitar $69 \%$. Hewan pengerat yang paling banyak digunakan diantaranya adalah tikus (Rattus norvegicus) dan mencit (Mus musculus). Tikus dan mencit banyak digunakan karena memilki sistem faal yang mirip dengan manusia (Fitria dan Sarto, 2014). Kondisi lingkungan yang baik untuk hewan pengerat yang digunakan untuk percobaan adalah ruangan dengan suhu $22^{\circ} \mathrm{C}\left( \pm 3^{\circ} \mathrm{C}\right)$, kelembaban relatif $30-70 \%$, dan penerangan 12 jam terang dan 12 jam gelap (Harmita dan Radji, 2008).

Inflamasi merupakan respon pertahanan tubuh terhadap invasi benda asing, kerusakan jaringan atau keduanya. Penyebab inflamasi antara lain mikroorganisme, trauma mekanis, zat-zat kimia dan pengaruh fisika, gejala respon antiinflamasi meliputi rubor (kemerahan), kalor (panas), dolor (nyeri) dan tumor (pembengkakan) (Corwin, 2008). Inflamasi atau radang merupakan proses respon tubuh terhadap rangsangan merugikan yang ditimbulkan oleh berbagai agen berbahaya seperti infeksi, antibodi ataupun luka fisik (Goodman dan Gilman, 2006). Salah satu aktivitas antiinflamasi flavonoid yaitu menghambat akumulasi leukosit di daerah inflamasi (Hidayati et al., 2005). Pengobatan pasien dengan inflamasi pada umumnya untuk memperlambat atau membatasi proses kerusakan jaringan yang terjadi pada daerah inflamasi.

Obat modern yang biasa digunakan ialah obat antiinflamasi non steroid (AINS) yang memiliki efek samping merugikan tubuh seperti tukak lambung (Tjay dan Rahardja, 2007). Oleh karena itu pemanfaatan tumbuhan obat dengan khasiat antiinflamasi perlu dilakukan untuk menemukan alternatif pengobatan dengan efek samping yang relatif lebih kecil (Narande dkk., 2013). Obat antiinflamasi dapat digunakan secara oral maupun topikal di tempat radang. Penggunaan topikal umumnya lebih baik digunakan karena tidak melewati first pass effect dan tidak melewati saluran pencernaan. Selain itu obat golongan NSAID memiliki efek samping mengiritasi lambung (Sativa dkk., 2014). Saat ini banyak dilakukan penelitian yang menelaah tentang aktivitas farmakologik dari kulit buah manggis (Garcinia mangostana L.). terdapat beberapa senyawa penting pada ekstrak kulit buah manggis yang memiliki aktivitas sebagai antiinflamasi, yakni $\gamma$-mangostin dan flavonoid. Kandungan $\gamma$ mangostin pada kulit buha manggis diketahui dapat menghambat jalur aktivitas siklooksigenase (COX2) dan dapat menurunkan level dari $\mathrm{PGE}_{2}$ (Nakatani dkk., 2004). Oleh karena itu, penelitian ini dilakukan untuk mengetahui aktivitas antiinflamasi dan dosis paling efektif gel ekstrak kulit manggin dalam penurunan volume edema mencit putih galur Swiss yang diinduksi karagenan.

\section{METODE PENELITIAN}

\section{Tempat dan Waktu}

Penelitian ini dilakukan di Laboratorium Percobaan Hewan, Program Studi Farmasi Fakultas Matematika dan Ilmu Pengetahuan Alam, Universitas Udayana. Waktu pelaksanaan dilakukan pada Oktober hingga November 2019.

\section{Alat dan Bahan}

Peralatan yang digunakan untuk penelitian ini adalah timbangan neraca analitik, kertas $\mathrm{pH}$, spuit $1 \mathrm{cc}$, stopwatch, plastik urin, cat kuku, kawat, gelas beker (Pyrex), pletishmometer, pinset dan sekam.

Bahan yang digunakan dalam penelitian ini adalah konsentrat (511), air mineral, gel Natrium Diclofenak (Voltaren emulgel), gel manggis (konsentrasi $0,005 \% ; 0,1 \% ; 0,2 \%$ ), karagenan, Normal Saline $\mathrm{NaCl}$ 0,9\% Widastra), dan mencit jantan usia 6-8 minggu dengan bobot \pm 20 gram

\section{Rancangan Percobaan}

Penelitian tentang "Uji Anti-Inflamasi Udema Pada Mencit" ini merupakan penelitian eksperimental murni dengan rancangan acak lengkap dengan pola percobaan tunggal sederhana. Metode yang digunakan untuk uji efek 
antiinflamasi dalam penelitian ini adalah metode carrageenan-induced paw edema.

Enam ekor mencit uji dibagi menjadi 2 kelompok uji. Kelompok I sebagai kelompok kontrol (1 ekor mencit untuk Kontrol Positif, 1 ekor mencit untuk Kontrol Negative dan 1 ekor mencit untuk Kontrol Normal) dan kelompok II sebagai kelompok uji sebanyak 3 ekor mencit. Ditandai kaki kanan belakang mencit pada bagian siku. Diukur dan dicatat volume kaki kanan belakang mencit menggunakan alat plethysmometer $\left(\mathrm{V}_{0}\right)$. Pada tiap kaki kanan belakang mencit kontrol negatif dioleskan 100mg basis sediaan uji, pada mencit kontrol positif dioleskan 100mg voltaren emulgel dan pada kontrol normal tidak diberikan apapun. Pada kelompok II dioleskan 100mg sediaan uji (konsentrasi $0,05 \%$ pada minggu I, konsentrasi 0,1 pada minggu II, konsentrasi $0,2 \%$ pada minggu III) sambil dipijat hingga 20 kali). Setelah diberi perlakuan, terhadap kaki kanan belakang mencit seluruh kelompok kecuali kelompok kontrtol normal diinjeksikan larutan karagenan sebanyak $0,1 \mathrm{~mL}$. Diukur volume kaki kanan belakang mencit hingga tanda batas yang telah diberikan pada menit ke-0, 30, 60, dan 90 terhitung setelah pemberian injeksi karagenan $(\mathrm{Vt})$. Dicatat hasil pengamatan pada tabel pengamatan. Dihitung persen inflamasi kelompok I dan kelompok II. Dihitung juga persen aktivitas antiinflamasi sediaan uji. Dilakukan pengulangan sebanyak tiga kali pada masingmasing kelompok uji.

\section{Pelaksanaan Penelitian}

\section{Adaptasi Hewan}

Penimbangan Mencit

Ditandai mencit 1-6 dengan spidol, disiapkan neraca analitik dengan dilengkapi beaker glass yang diletakkan terbalik di atas timbangan. Ditimbang mencit satu persatu dari nomor 1-6 dengan cara meletakkan mencit diatas beaker glass. Dicatat bobot mencit yang diperoleh. Tandai masing-masing mencit dengan nomor 1-6 pada bagian kepala, punggung dan ekor mencit sesuai dengan Peraturan BPOM Nomor 7.

\section{Pemeriksaan Awal Mencit}

Mencit disiapkan pada kandang perlakuan, kemudian masing-masing mencit ditung pergerakannya menggunakan stopwatch, volume urin awal, warna urin dan $\mathrm{pH}$ urin.

\section{Pembuatan Larutan Karagenan 1\% (Penginduksi Inflamasi)}

Dibuat larutan karagenan sebanyak $10 \mathrm{~mL}$ dengan kadar $1 \% \mathrm{~b} / \mathrm{v}$ dalam Normal saline $(\mathrm{NaCl}$ $0,9 \%)$. Ditimbang 0,1 gram karagenan kemudian dilarutkan dengan $\mathrm{NaCl}$ hingga $10 \mathrm{~mL}$ dalam gelas beaker.

\section{Variabel yang Diamati}

Variabel yang diamati adalah perubahan volume inflamasi kaki mencit per satuan waktu terhadap pemberian gel kulit manggis. Dihitung persen inflamasi dengan persamaan sebagai berikut:

Keterangan:

$$
\% \text { Inflamasi }=\frac{\boldsymbol{V} \boldsymbol{t}-\boldsymbol{V 0}}{\boldsymbol{V o}} \times 100 \%
$$

$$
\begin{aligned}
& \mathrm{Vt}= \text { Volume Inflamasi Kaki mencit per } \\
& \text { satuan waktu } \\
& \mathrm{Vo}=\text { Volume Kaki Awal mencit }
\end{aligned}
$$

\section{Analisis Data}

Data hasil pengamatan dikumpulkan dan disajikan dalam bentuk tabel, grafik dan analisis statistik uji one way ANOVA (Analysis of Variance). Data \%antiinflamasi terhadap waktu dilakukan uji Kolmogorof Smirnov untuk mengetahui data terdistribusi normal atau tidak. Levene Statistic test untuk mengetahui homogenitas variannya. Data yang telah terdistribusi normal dan homogen dilanjutkan dengan analisi varian satu jalan (Oneway Difference) dengan taraf kepercayaan $95 \%$ dan dilanjutkan uji LSD (Least Significant Difference) untuk mengetahui ada atau tidaknya perbedaan bermakna. Analisis data dikerjakan dengan program SPSS.

\section{HASIL DAN PEMBAHASAN}

Hasil penimbangan pada masing-masing mencit diperoleh bobot mencit sebesar 21,6 gram; 25,5 gram; 24,9 gram; 20,2 gram; 18,7 gram; dan 22,7 gram. Diperoleh bobot mencit yang bervariasi dan sesuai untuk dijadikan sebagai hewan coba yaitu dengan bobot berkisar antara 15 gram sampai dengan 25 gram (BPOM RI, 2014). Mencit yang telah ditimbang bobotnya dilakukan penandaan pada mencit pertama hingga ke-enam dengan penanda yang lebih permanent. Penandaan dilakukan untuk membedakan antara hewan yang satu dengan yang lainya.

Hasil yang diperoleh pada volume $\left(\mathrm{V}_{0}\right)$ kaki mencit setelah diukur dengan alat plethysmometer pada kelompok uji adalah 0,1467 $\pm 0,005774 \mathrm{~mL}$. Sedangkan volume $\left(\mathrm{V}_{0}\right)$ pada kelompok kontrol positif, kontrol negatif dan normal berturut-turut adalah $0,15 \mathrm{~mL} ; 0,14 \mathrm{~mL}$ dan $0,15 \pm 0,005774 \mathrm{~mL}$ Mencit kemudian diberikan perlakuan dimana mencit yang tergolong dalam kelompok 1 (kelompok uji) diberikan perlakuan dengan mengoleskan kaki kanan belakang mencit dengan 
gel manggis dengan variasi konsentrasi yakni $0,05 \%, 0,1 \%$, dan $0,2 \%$ sebanyak $100 \mathrm{mg}$, dan mencit yang tergolong kedalam kelompok 2 (kelompok kontrol) setiap mencit diberikan perlakuan yang berbeda, mencit VIII sebagai kontrol negatif dioleskan $100 \mathrm{mg}$ basis pada kaki kanan belakang, mencit III sebagai kontrol positif dioleskan $100 \mathrm{mg}$ Voltaren emulgen pada kaki kanan bagian belakang, dan mencit II sebagai kontrol normal tidak diberikan perlakuan apapun. Diinjeksikan dengan larutan karagenan sebanyak 0,1 mL pada bagian kaki kanan semua mencit. Diukur kembali volume kaki mencit yang telah diinjeksikan dengan larutan karagenan (Vt) mulai dari menit ke-0, ke-30 ,ke-60 dan ke-90. Pada masing-masing kelompok uji dilakukan pengulangan sebanyak tiga kali.

Pada kelompok uji dengan pemberian gel ekstrak manggis $0,05 \%$ menit dilakukan pengukuran kembali terhadap volume kaki mencit. Diperoleh hasil pada pada saat $\mathrm{t}=30$ adalah $0,26 \pm$ $0,01 \mathrm{~mL}, \mathrm{t}=60$ adalah $0,216760 \pm 0,00577 \mathrm{~mL}$, dan $\mathrm{t}=90$ adalah $0,1967 \pm 0,00577$. Sedangkan pada kelompok kontrol diperoleh hasil dari kontrol positif yaitu $0,25 \pm 0,1 \mathrm{~mL}$.

Pada kelompok uji dengan pemberian gel ekstrak manggis $0,1 \%$ menit dilakukan pengukuran kembali terhadap volume kaki mencit. Diperoleh hasil pada pada saat $\mathrm{t}=30$ adalah $0,263 \pm$ $0,0289 \mathrm{~mL}, \mathrm{t}=60$ adalah $0,21 \pm 0,02 \mathrm{~mL}$, dan $\mathrm{t}=90$ adalah $0,173 \pm 0,0213$. Sedangkan pada kelompok kontrol diperoleh hasil dari kontrol positif yaitu $0,19 \pm 0,1 \mathrm{~mL}$.

Pada kelompok uji dengan pemberian gel ekstrak manggis $0,2 \%$ menit dilakukan pengukuran kembali terhadap volume kaki mencit. Diperoleh hasil pada pada saat $\mathrm{t}=30$ adalah 0,277 \pm $0,0057879 \mathrm{~mL}, \mathrm{t}=60$ adalah $0,2223 \pm$ $0,0057879 \mathrm{~mL}$, dan $\mathrm{t}=90$ adalah $0,177 \quad \pm$ $0,0057879 \mathrm{~mL}$. Sedangkan pada kelompok kontrol diperoleh hasil dari kontrol positif yaitu $0,16 \mathrm{~mL}$

Berdasarkan hasil pengamatan tersebut, didapat perhitungan persen inflamasi dari masingmasing variasi konsentrasi gel ekstrak kulit manggis terhadap waktu penurunan volume udem pada kaki mencit.

Tabel 1. Data Perbandingan Penurunan Inflamasi

\begin{tabular}{lccc}
\hline Jenis Konsentrasi & \multicolumn{3}{c}{ Waktu \% Antiinflamasi (Menit) } \\
\cline { 2 - 4 } & 30 & 60 & 90 \\
\hline Konsentrasi gel 0.05\% & 29.27 & 53.3 & 66.67 \\
Konsentrasi gel 0.1\% & 25.07 & 55.2 & 82.33 \\
Konsentrasi gel 0.2\% & 18.98 & 48.8 & 79.85 \\
Kontrol positif & 47.26 & 73.9 & 93.59 \\
\hline
\end{tabular}

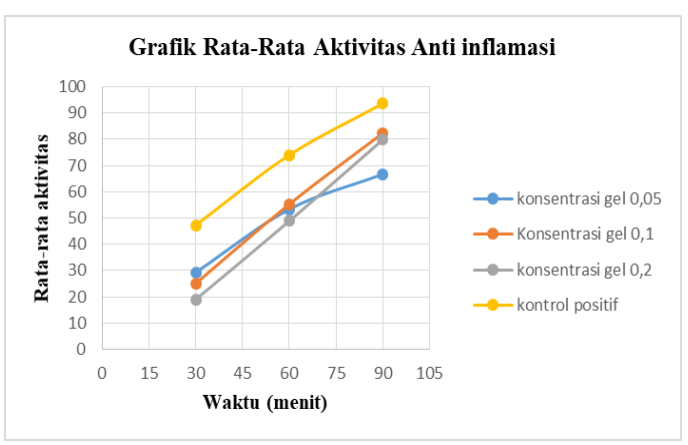

Gambar 1. Grafik rata-rata Aktivitas Anti Inflamasi

Setelah diperoleh data tersebut nomal dan homogen maka dilanjutkan dengan uji One Way ANOVA yaitu uji LSD dengan taraf kepercayaan 95\%.. Berdasarkan hasil uji LSD nilai $\%$ antiinflamasi, konsentrasi gel $0,05 \% ; 0,1 \%$; $0,2 \%$ tidak berbeda bermakna dengan kontrol positif $(\mathrm{P}>0,05)$ sehingga dapat diasumsikan bahwa konsentrasi gel memiliki efek antiinflamasi yang relative sama.

Grafik di atas menunjukkan hasil bahwa gel ektrak kulit manggis dengan konsentrasi $0,1 \%$ pada $\mathrm{t}($ menit $)=60$ dan $\mathrm{t}($ menit $)=90$ menunjukkan aktivitas antiinflamasi paling tinggi dibandingkan dengan gel konsentrasi $0,05 \%$ dan $0,2 \%$. Selain itu, aktivitas inflamasi dari gel ekstrak dengan konsentrasi $0,1 \%$ mendekati garis kontrol positif yang menunjukkan bahwa aktivitas antiinflamasinya relatif sama dibandingkan gel antiinflamasi. Dalam penelitian ini terdapat keterbatasan terhadap jumlah sampel yang digunakan. Pengamatan terhadap masing-masing sampel dalam setiap kelompok dilakukan secara berulang dengan memperhatikan kondisi awal sampel, yakni dilakukan dalam waktu yang berbeda sehingga sampel kembali berada dalam kondisi normal. Sehingga data yang diperoleh tetap dapat dianalisis menggunakan analisa ANOVA.

\section{SIMPULAN}

Pemberian gel manggis memberikan respon positif terhadap penurunan ukuran udema kaki mencit (Mus muculus L.) pengukuran volume udem dibandingkan dengan kontrol positif dan kontrol negatif. Dari persentase penghambatan yang dihitung dan konsentrasi gel yang efektif adalah konsentrasi $0,1 \%$ karena memiliki efektivitas yang relatif sama dengan persen antiinflamasi dengan kontrol positif. 


\section{DAFTAR PUSTAKA}

BPOM RI. 2014. Peraturan Badan Pengawas Obat dan Makanan Republik Indonesia tentang Pedoman Uji Toksisitas Nonklinik secara In Vivo. Nomor 7. Badan Pengawas Obat dan Makanan. Jakarta.

Corwin E.J. 2008. Buku Saku Patofisiologi Corwin. Jakarta: EGC.

Fitria, L., dan M. Sarto. 2014. Profil Hematologi Tikus (Rattus norvegicus Berkenhout, 1769) Galur Wistar Jantan dan Betina Umur 4, 6, dan 8 Minggu. Biogenesis Jurnal Ilmiah Biologi. 2 (2): 94-100.

Goodman and Gilman. 2008. Manual Farmakologi dan Terapi. Jakarta: Buku Kedokteran EGC.

Harmita dan Radji, M., 2008. Kepekaan Terhadap Antibiotik. Jakarta: EGC.

Meles, D.K dan W. Sastrowardoyo. 2010. Efek Infusa Impaties Balsamina Linn pada Stadium Pembelahan Sel (cleavage) Dalam Upaya Pencarian Obat Antifertilitas. Surabaya: Lemlit Universitas Airlangga.
Nakatani, K., T. Yamakuni, N. Kondo, T. Arakawa, K. Oosawa, S. Shimura, H. Inoue and Y. Ohizumi. 2004. $\gamma$ mangostin Inhibits Inhibitor-kB Inase Activity and Decreases Lipopolysaccharide-Induced

Cyclooxygenase-2 Gene Expression in C6 Rat Glioma Cells. Molecular Pharmacology. 66: 1718-1723.

Narande, J.M., Wulur, A., Yudistira, A. 2013. Uji Efek Antiinflamasi Ekstrak Etanol Daun Suji (Dracaena angustifolia Roxb) Terhadap Edema Kaki Tikus Putih Jantan Galur Wistar. Pharmacon Jurnal Ilmiah Farmasi. 2 (3):14-18.

Sativa, O., Yuliet, Y., \& Sulastri, E. (2014). Uji Aktivitas Antiinflamasi Gel Ekstrak Buah Kaktus (Opuntia elatior Mill.) Pada Tikus (Rattus norvegicus L.) Yang Diinduksi Lamda Karagenan. Natural Science: Journal of Science and Technology, 3(2).

Tjay, Tan Hoan dan Kirana Rahardja. 2007. ObatObat Penting Khasiat, Penggunaan dan Efek-Efek Sampingnya. Edisi Keenam. Jakarta: PT. Elex Media Komputindo. 